\title{
Factors Causing Claims on Perintis Airport Construction Project
}

\author{
Irmanzah $^{1}$, Nunung Widyaningsi ${ }^{2}$, Bambang Purwoko Kusumo Bintoro ${ }^{3}$ \\ ${ }^{1}$ Students of the Civil Engineering Master Program at Mercubuana University, Jakarta Indonesia \\ ${ }^{2}$ Lecturer in Civil Engineering, Mercubuana University \\ ${ }^{3}$ Lecturer in Civil Engineering, Mercubuana University
}

Corresponding Author: Irmanzah

\begin{abstract}
Kabir Airport in Alor Regency is the second entrance to Alor Regency after Mali Airport, it is expected that there will be an increase in the economy. The airport is currently under construction and the construction plan for 2019 is completed. With the development of both existing facilities and infrastructure is expected to facilitate the flow of passengers, goods and services to enter Pantar Island, so as to increase regional income. The work of Airport Infrastructure Implementation on Kabir Island is divided into several parts of the infrastructure, namely facilities including the air side area (runway, apron), land side area (passenger terminal, parking area, hangar, tower, etc.). The implementation of Kabir airport applies the thematic "Eco Friendly" approach. Because through this approach, in addition to awareness of environmental sustainability, it also influences the object of implementation, using an Eco Friendly theme approach
\end{abstract}

Keywords: Airport, Air Transportation, Eco Friendly, Structural Equation Modeling (SEM).

\section{PRELIMINARY}

Indonesia is the largest archipelagic country in the world which spreads from Sabang to Merauke. There are still many isolated areas and public relations with outsiders are still very limited. In this case, the Pantar island sub-district is included in the category of underdeveloped / isolated areas, where the location of the Pantar subdistrict is on the island of Pantar, Mali Regency, East Nusa Tenggara (NTT).
Accessibility to Pantar Island is currently only possible using sea transportation, namely from Kalabahi port, Alor Regency city and Waiwa port, East Flores Regency. The Pantar Strait, which separates Pantar Island from Alor Island, is difficult for motorized boats to pass through certain seasons because of the strong currents and high waves, looking at the background of the Pantar region, the existence of air transportation is the best choice.

The existence of an airport is very necessary to open the isolated and underdeveloped areas, according to Presidential Decree No. 7 of 2004 and the Decree for the Acceleration of Disadvantaged Areas No. 001 / KEP / MPDT / II / 2005.

The implementation of airport services to be realized optimally, in this case it is still necessary to pay attention to regional spatial planning, economic growth, environmental sustainability, national aviation security and safety.

In this case, Printis Airport is the research material for the author's thesis, namely Kabir Airport, the location of the Kabir Airport in Pantar Island, Mali Regency, East Nusa Tenggara Province (NTT).

\section{LITERATURE REVIEW Construction Project}

Project is a temporary activity that takes place in a limited period of time, with 
the allocation of certain resources and is intended to carry out tasks whose objectives have been clearly outlined (Soeharto, 1995).

The characteristics of the project (Soeharto, 1995) are: Has a specific goal, the final product or the final work, the total cost, the target schedule and the quality criteria in the process of achieving project objectives have been determined, Temporary, in the sense that his age is limited by the completion of his duties, nonroutine, not repeated. The type and intensity of activities change based on project.

\section{Project Management}

The definition of project management, planning ranks first of other functions such as organizing, leading, and controlling. Planning is a process that tries to lay the foundation for goals and objectives including preparing all resources to achieve them (Soeharto, 1995). The main key to the success of executing a project on time is complete and precise project planning and scheduling. Project delays are often a source of disputes and demands between owners and contractors, so that project delays will be very expensive in value both from the perspective of the contractor and the owner. The contractor will be subject to penalty penalties in accordance with the contract, in addition, the contractor will also experience additional overhead costs while the project is still going.

\section{Project Planning}

Planning is one of the most important project management functions, namely determining the steps for future activities needed to achieve the target. The first determining the goals to be achieved then arranging a sequence of activity steps to achieve them. Planning is intended to bridge between the goals to be achieved and the situation or situation at the beginning (Soeharto, 1990). Project schedule planning can be done properly and realistically, if the schedule planning process is carried out in stages with the following steps:
- Identify the types of project activities.

- Determine the duration of each activity in accordance with the productivity of existing resources.

- Determine the relationship between activities, and the order of work between one activity and another.

- Looking forward the duration and sequence of activities make sense and can be carried out in the field.

\section{Project Delay}

The definition of delay is a portion of the implementation time that cannot be utilized according to plan, causing some of the following activities to be delayed or cannot be completed exactly according to the planned schedule (Ervianto, 2004).

Project delays can be caused by the contractor, owner, or caused by natural and environmental conditions beyond human capacity or is called force majeure.

\section{Claim Management}

Claims can be interpreted as requests or demands for compensation of money or fees or schedules outside the contract (Soeharto, 1999). In the world of construction, claims can be interpreted as problems that can lead to disputes and requests for additional money, additional implementation time, or changes in the method of carrying out work. Claims continue with the creation of a formal claim document submitted by the Contractor to the building owner. This will form the basis of the building owner's policy to consider potential claims as early as possible. In this case, the Claims in the Construction Contract include the factors that cause claims and claim settlement.

\section{Research Methods}

In this study, using a quantitative approach, the method of collecting data in accordance with the actual situation, as well as presenting and analyzing so that it can provide a clear picture of the object under study. This study aims to determine and analyze the causes of claims at the Pioneer 
Airport construction work. In terms of success towards: In terms of construction, namely the cost factor; time; quality and risk factors and claims, where the success factors are very difficult to avoid, as long as the system / policy is not revised and in terms of supporting factors, namely management factors, airline / airland factors and local government factors and the surrounding community.

The variables contained in this study consist of two independent variables (X) and two dependent variables (Y). The independent variables contained in this study are Project Owner (X1), Development Planner (X2) and Project Characteristics (X3), while the independent variable is Project Performance (Y1).

In this study used Partial Least Square (PLS) where this type of analysis is an alternative method based on variants of the Structural Equation Modeling (SEM) method. The PLS method has advantages compared to the CB-SEM method because the sample size is not too large, ranging from 30-100 and the data does not have to have a normal multivariate distribution (Ghozali, 2006). PLS SEM (Partial least Square Structural Equation Modeling) research is a research for multivariate statistical techniques that can handle many variables as well as explanatory variables. This analysis is a good alternative for multiple regression analysis methods and principal component regression, this method is more robust.

\section{Research Location}

Kabir is located on Pantar Island, precisely in Pantar District, where the position of Pantar Island is located at the eastern tip of the Nusa Tenggara Islands, which is one of the two main islands in Alor Regency. Alor Regency is located between 80 - 60 to 80 - 360 South Latitude and 230 480 to 1250 - 80 East Longitude, in accordance with local regulation No.15 of 2005.

\section{Research Sample}

The sample that is determined as the subject in the research conducted includes stakeholders who have a direct relationship and are able to have a direct impact in the process of pioneering airport construction work.

Therefore, the information in this study is the construction implementer and the respondents who are intended as samples, namely:

- Owner.

- User / public.

- Construction Planning / Supervision Consultants and Construction Implementing Contractors.

The number of samples in this study amounted to 86 respondents / construction workers.

\section{Type of Data}

To get the objectives of the research, this study are data needed in:

\section{Primary Data}

Data obtained from construction worker respondents at pioneer airport construction work by distributing questionnaires and conducting direct interviews.

\section{Secondary Data}

Data obtained from general project data and literature and media related to the object study.

\section{ANALYSIS AND DISCUSSION Evaluation of the Measurement Model}

The evaluation of the research model is carried out using the outer model and inner model testing. Outer model, which is the initial stage, is the evaluation of the measurement model which aims to measure the validity and reliability of the research model to be tested.

This test is intended to assess whether the research model is valid and reliable with the measurement model parameters of the convergent validity test by looking at the loading factor and AVE values, the discriminant validity test by looking at the AVE value and its correlation with the 
latent variable and the cross loading value. While the parameter measurement model is the reliability test by looking at the results of the Cronbach alpha value and composite reliability (R) as the prediction model parameters.

\section{Convergent Validity Test}

Convergent validity test is performed to test whether the variables of a construct are highly correlated. In accordance with the rule of thumb used in this study, the measurement parameter is the loading factor value greater than 0.7 and AVE greater than 0.5. The test results using SmartPLS produce the loading factor value in the model path diagram image and the following table.

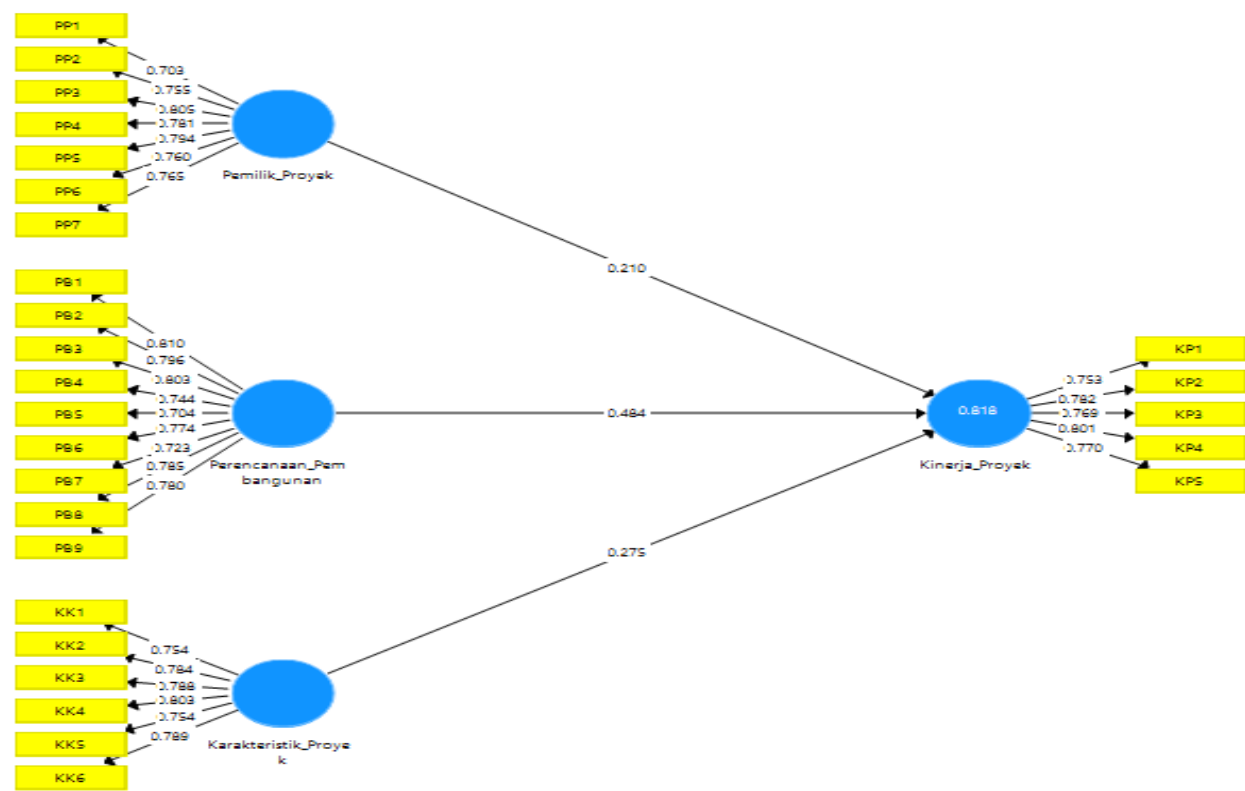

Image 1. Research Model Path Diagram After Calculate, (Source. Analysis Results, 2020)

Table 1. Loading Factor

\begin{tabular}{|c|c|c|c|c|}
\hline & Project Owner & Development Planner & Project Characteristics & Project Performance \\
\hline PP1 & 0.703 & & & \\
\hline PP2 & 0.755 & & & \\
\hline PP3 & 0.805 & & & \\
\hline PP4 & 0.781 & & & \\
\hline PP5 & 0.794 & & & \\
\hline PP6 & 0.760 & & & \\
\hline PP7 & 0.765 & & & \\
\hline PB1 & & 0.810 & & \\
\hline PB2 & & 0.796 & & \\
\hline PB3 & & 0.803 & & \\
\hline PB4 & & 0.744 & & \\
\hline PB5 & & 0.704 & & \\
\hline PB6 & & 0.774 & & \\
\hline PB7 & & 0.723 & & \\
\hline PB8 & & 0.785 & & \\
\hline PB9 & & 0.780 & & \\
\hline KK1 & & & 0.754 & \\
\hline KK2 & & & 0.784 & \\
\hline KK3 & & & 0.788 & \\
\hline KK4 & & & 0.803 & \\
\hline KK5 & & & 0.754 & \\
\hline KK6 & & & 0.789 & \\
\hline KP1 & & & & 0.753 \\
\hline KP2 & & & & 0.782 \\
\hline KP3 & & & & 0.769 \\
\hline KP4 & & & & 0.801 \\
\hline KP5 & & & & 0.770 \\
\hline
\end{tabular}


Based on the results of outer loading shown in table 1, it can be concluded that all indicators in the study have a loading factor value above 0.7 , which means that the indicators are said to be valid. The next step is to test with the measurement parameter of average variance extracted (AVE) $>0.5$.

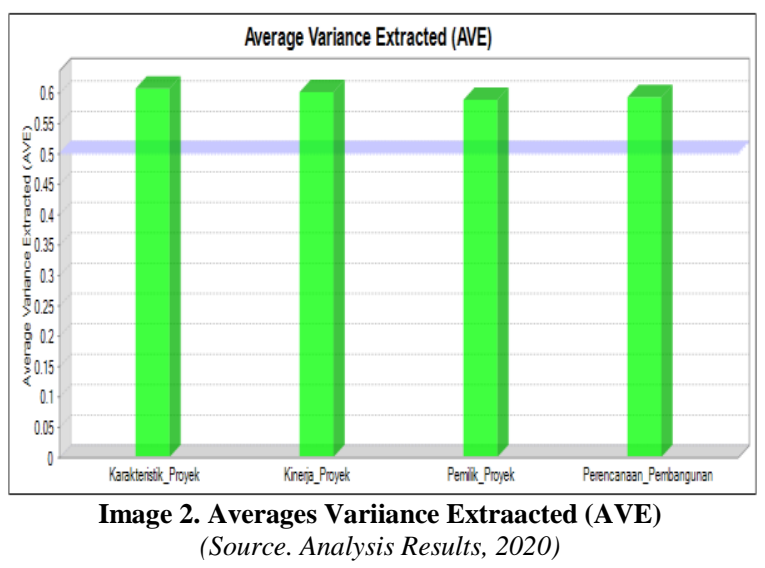

Figure 2 shows the value of Composite Reliability (CR) and Average Variance Extracted (AVE). A variable is said to have a valid indicator if the AVE value is $>0.5$. Meanwhile, a variable is said to have a reliable indicator if the $\mathrm{CR}$ value is> 0.7. Based on Figure 2, that variables have an AVE value> 0.5, which means that all variables in this study have valid indicators. Likewise, based on table 1 that all variables have a $C R$ value $>0.7$, which means that all the variables of this study have reliable indicators.

\section{Reliability Test}

Reliability test is carried out to measure the internal consistency of the measuring instrument. There are two measurement methods: first with the Cronbach alpha (CA) method and the second with the composite reliability (CR) method as a parameter of the prediction model. To meet the reliability test, the value of Cronbach alpha (CA) and composite reliability (CR) must have> 0.7 .

The test results contained in table 2 , it can be seen that the Cronbach's alpha value in all variables in this study using the SmartPLS application is more than 0.7. Meanwhile, the value of composite reliability for all constructs has a value above 0.7 . So that from the results obtained from the test above, it can be said that all constructs in the model have passed the reliability test.

\begin{tabular}{|c|c|c|}
\hline & $\begin{array}{l}\text { Composite } \\
\text { Realibility }\end{array}$ & $\begin{array}{l}\text { Average Variance Extracted } \\
\text { (AVE) }\end{array}$ \\
\hline $\mathrm{PP}$ & 0.909 & 0.588 \\
\hline PB & 0.929 & 0.592 \\
\hline KK & 0.902 & 0.607 \\
\hline KP & 0.883 & 0.601 \\
\hline
\end{tabular}

\section{Evaluation of the Measurement Model}

Evaluation of the measurement model discusses the inner model. R-Squares are categorized into 3 categories, namely, $0.19<\mathrm{R} 2<0.32$ as the weak category, 0.33 $<\mathrm{R} 2<0.67$ as the moderate category, and R2 .0 .67 as the strong category. Table 3 below is the estimation result of R-Squares.

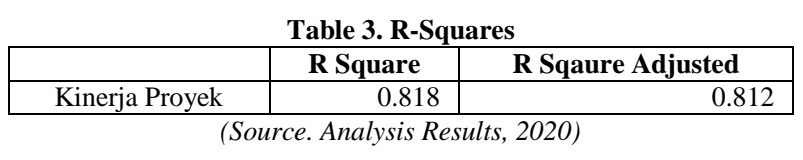

Based on the R-Square value above, it can be seen that the results of the RSquare value on the project performance variable of 0.818 are included in the strong category. This means that the variable project owner, development planning and project characteristics have an effect of $81.8 \%$ on project performance, while the remaining $18.2 \%$ is influenced by other factors.

\section{Hypothesis Test}

The next is to evaluate the t-statistics value of each path to see the significance between constructs. To get predictiveness, bootstrapping can be obtained to obtain stability from the estimation. Bootsrapping is resampling, PLS uses bootstrapping to determine the value of $t$-statistics so that it can find out the level of significance value of the t-statistics value. The recommended value of T-statistics must be above 1.96 for a two-tailed hypothesis at 5\% alpha. This research uses the two tailed hypothesis method. 


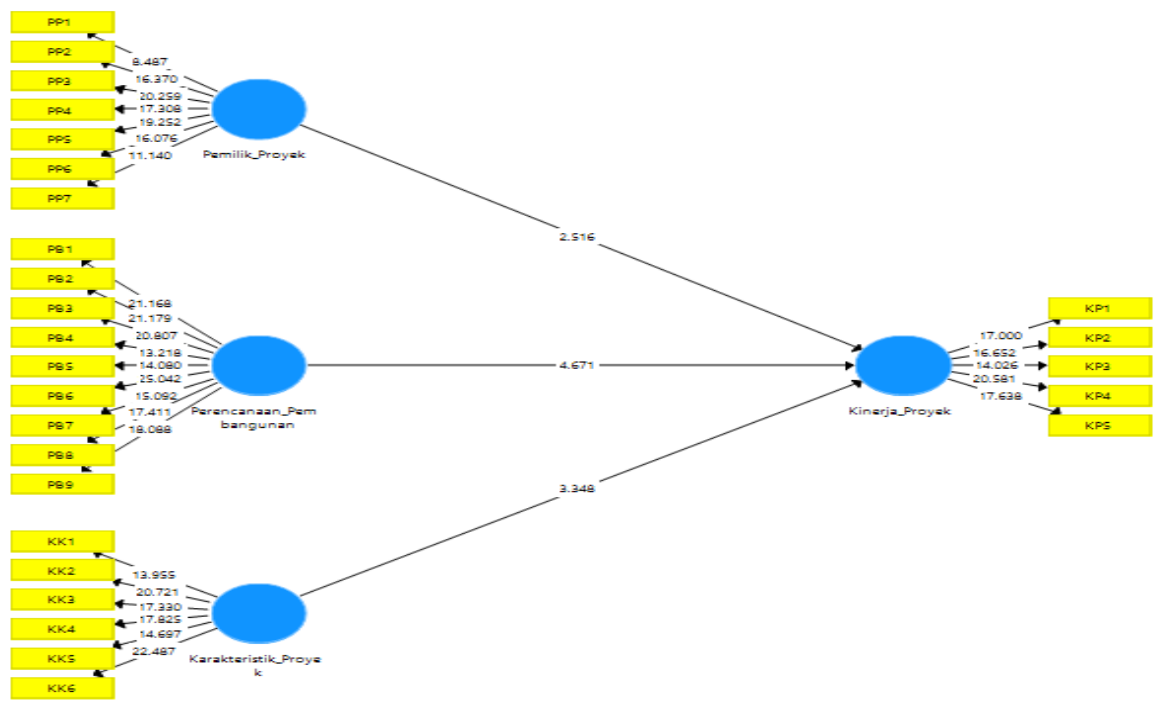

Image 3. Research Model Path Diagram After Bootstrapping (Source. Analysis Results, 2020)

Based on the T-statistics column, all variables have a value above 1.96 according to the rule of thumb established in this study. This means that all hypotheses are accepted because they have a score above 1.96.

\begin{tabular}{|c|c|c|}
\hline & $\begin{array}{l}\text { T Statistics } \\
\text { (|O/STDEV }\end{array}$ & P Values \\
\hline $\mathrm{PP} \rightarrow \mathrm{KP}$ & 2.406 & 0.016 \\
\hline $\mathrm{PB} \rightarrow \mathrm{KP}$ & 4.575 & 0.000 \\
\hline $\mathrm{KK} \rightarrow \mathrm{KP}$ & 3.296 & 0.001 \\
\hline
\end{tabular}

Based on table 4 it can be concluded that all hypotheses are accepted, there is:

- The Project Owner variable affects the Project Performance, seen from the Tstatistics value of 2.406 ( $>1.96$ for the two-tailed hypothesis).

- The Development Planning Team variable has an effect on project performance, seen from the T-statistics value of 4.575 (> 1.96 for the two-tailed hypothesis).

- Project Characteristics Variables affect project performance, seen from the $\mathrm{T}$ statistics value of 3.296 (> 1.96 for the two-tailed hypothesis).

\section{The Effect of Project Owner on Project Performance}

The first hypothesis test shows that there is an effect of project owner variables on project performance with the results of the analysis of the T-statistics value of 2.406. The results of this study indicate that the project owner has an influence on project performance. The ability of the project owner in evaluating the performance results of the development team and the availability of assisting experts or consultants to assist the project owner during project work have an effect on project performance. In their research, they found that the factor of the project owner had a significant effect on project performance.

\section{The Effect of Development Planning on Project Performance}

The second hypothesis test shows that there is an influence of the development planning variable on project performance and has a number one big influence which can be seen from the results of the analysis of the T-statistics value of 4.575 . The results of this study indicate that development planning has an influence on project performance. Experience and understanding of the planning team in making designs on this project affects the quality, time and cost of the project. In their research, they found that development planning factors had a significant effect on project performance. 


\section{The Effect of Project Characteristics on Project Performance}

The third hypothesis test shows that there is an effect of project characteristics variables on project performance with the results of the analysis of the T-statistics value of 3.296. The results of the above research indicate that cost performance is influenced by licensing risk. The fact of the research result is in accordance with the opinion expressed by the respondent which states that the project can be completed with the planned budget if the permit for project work has been issued by the government and completed legally. Establishment of guidelines for LVC (Land Value Capture) as a financing tool developed from the law Permen ATR no. 16 ATR no. 16 ATR no. 16 of 2017.

\section{Implication}

Based on hypothesis testing, it was found that the project owner, development planning team and project characteristics had an influence of $81.8 \%$ on project performance, while the remaining $18.2 \%$ was influenced by other factors.

Based on the results of this study, the practical implication is that development planning and project characteristics have a positive influence on project performance in the construction of Kabir airport in the island of Pantar, Mali Regency, East Nusa Tenggara (NTT), with the following details:

1. Based on hypothesis testing, it is found that the project owner has a positive influence on project performance in the construction of Kabir airport in the island of Pantar, Mali Regency, East Nusa Tenggara Province (NTT). This is due to the suitability of performance for timeliness, responsiveness and accuracy in work and the existence of an accuracy factor, namely the suitability of project reports with actual conditions in the field.

2. Based on hypothesis testing, it is found that development planning has a positive influence on project performance in the construction of Kabir airport in the island of Pantar, Mali Regency, East Nusa Tenggara Province (NTT). This indicates that success is strongly influenced by the quality of good planning, in this case planning is used as a reference for work activities as well as a standard for field implementation.

3. Based on hypothesis testing, it is found that the project characteristics have a positive influence on project performance in the construction of Kabir airport in the island of Pantar, Mali Regency, East Nusa Tenggara Province (NTT). This is expected to continue to make improvements to the resource factor, which greatly affects managerial and economic factors in the future.

\section{CONCLUSIONS AND SUGGESTIONS Conclusions}

1. The project owner has a positive influence on the project performance in the construction of Kabir Airport. This is due to the suitability of performance on timeliness, responsiveness and accuracy in work as well as the accuracy factor, namely the suitability of project reports with actual conditions in the field.

2. Development planning has a positive influence on Project Performance in the construction of Kabir Airport. This indicates that success is strongly influenced by the quality of good planning, in this case planning is used as a reference for work activities as well as a standard for field implementation.

3. Project characteristics have a positive influence on project performance in the construction of Kabir Airport. This is expected to continue to make improvements to the resource factor, which greatly affects managerial and economic factors in the future

\section{Suggestion}

1. Further research expected to be able add new variables that affect project performance in the construction of Kabir airport in Pantar Island, Mali Regency, 
East Nusa Tenggara Province (NTT) by involving other variables such as: Land Acquisition Risk, Licensing Risk, Safety Management, and others.

2. The results of hypothesis are testing found that the project owner has an effect on project performance, seen from the T-statistics value of 2.406. This variable has the lowest T-statistics among other variables so that the project in the construction of Kabir airport in Pantar Island, Mali Regency, East Nusa Tenggara Province (NTT) must increase its resources, such as human capabilities which will be a measure of the progress of the region, its economy and capabilities management.

\section{Acknowledgement: None}

\section{Conflict of Interest: None}

\section{Source of Funding: None}

\section{REFERENCES}

1. Arikunto, Suharsimi. 2006. Prosedur Penelitian Suatu Pendekatan Praktik, PT Rineka Cipta Jakarta.

2. Alaydrus, A. M., \& Hardjomuljadi, S. (2019). Analisis Faktor Keterlambatan Dimulainya Pelaksanaan Proyek Konstruksi Pada Model Kontrak Rancang Bangun. Konstruksia, 10(1), 95-116.
3. Basuki Rahardjo, 2012. Standar Rancang Bangun Dan Atau Rekayasa Bangunan Terminal Penumpang, SKEP Dirjen Perhub / 347 / XII / 1999.

4. Direktorat Jenderal Bandar Udara, 2004. Terminal Penumpang Bandar Udara. SNI 03-7046-2004, Perumusannya oleh Panitia Teknis Persyaratan Sarana dan Prasarana, Pengoperasian serta Pelayanan Transportasi Udara (74F).

5. Kongkoon Tochaiwat and Visuth Chovichien, 2004. Contactor's Construction Claims And Claim management Process. Jurnal International Chulalongkorn University.

6. Monecke, A. \& Leisch, F.(2012) SEM PLS: Structural Equation Modeling Using Partial Least Square. Journal of Statistic Software.

7. PMI. 2018. Pedoman Kerangka Ilmu Manajemen Proyek (PMBOK Guide). Edisi6. PMI Indonesia Chapter. Jakarta.

8. Sarwono Hardjomulyadi, 2015. Manajemen Klaim Konstruksi "Fidic Conditions Of Contract", Edisi 1 Cetakan ke 2, Penerbit Lagoz Publishing, Bandung.

9. Soeharto, Iman. 1997. Manajemen Proyek : dari konseptual sampai operasional. Cetakan ke-3. Erlangga. Jakarta.

How to cite this article: Irmanzah, Widyaningsi $\mathrm{N}$, Bintoro BPK. Factors causing claims on perintis airport construction project. International Journal of Research and Review. 2021; 8(5): 102-109. DOI: https://doi.org/ 10.52403/ijrr.20210515 